\section{Preli
and Re
Re} North American Ginseng

\author{
Jan Schooley ${ }^{1}$ and \\ John T.A. Proctor ${ }^{2}$
}

Additional indeX words. frost damage, Panax quinquefolius, plant health

Summary. The Lake Erie counties of southern Ontario, Canada are the major producers of ginseng (Panax quinquefolius) in North America. In this area there is about 1740 ha (4299.5 acres) of ginseng and an annual production of $1455 \mathrm{t}$ (1603.8 tons). Spring freeze damage to the crop is rare as the mean date of last freeze in spring is 12 May. On 21 May 2002, following three to six nights when air temperatures dropped below freezing, extensive damage to the crop was evident. A survey by the Ontario Ginseng Growers Association showed that $78 \%$ of growers had gardens showing freeze damage. The extent of the damage was variable across the growing area, and on individual farms. Most damage to plants occurred in low-lying areas where heavy cold air collected. Recently germinated seedlings that were exposed above the straw mulch were severely damaged, and many did not survive

This research was supported in part by J.C.K. Farms Ltd. and the Ontario Ministry of Agriculture and Food. We are indebted to Dean Louttit for technical assistance, and to ginseng grower, Jeff Rice, for use of ginseng gardens.

${ }^{1}$ Ontario Ministry of Agriculture and Food, Simcoe, Ontario, N3Y 4N5, Canada.

${ }^{2}$ Department of Plant Agriculture, Division of Horticultural Science, University of Guelph, Guelph, Ontario, NIG 2Wl, Canada. because they did not have leaves and no perennating bud was formed. Damage to 2-year-old plants was expressed as leaves wilting and turning black. In some cases stems froze and the plants toppled. In 3-year-old and older plants, damage was variable with some leaf collapse and stems broken, or damaged with corking-over taking place. Damage to inflorescences ranged from death and abscission, to distorted flowers and shriveled and split peduncles. Plant health was a concern following the freeze episode, and throughout the subsequent growing season. The fungicide fenhexamid received emergency registration to combat recurring problems in Botrytis control. The seed crop for 2002 was light. Damaged seedling gardens were replanted. Older gardens will undergo a period of adjustment. Root yield in 2002 was reduced by $30 \%$, a $500 \mathrm{t}$ (551.1 tons) loss. The full extent of the damage and associated financial implications are unknown and could impact the industry until 2005.

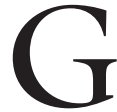
inseng is a slow-growing herbaceous perennial. It is a medicinal herb cultivated in North America in Ontario, British Columbia, and Wisconsin. The crop needs to grow 3 or 4 years to produce the highly valued root. Production in Canada in 2000 was about $2000 \mathrm{t}$ (2204.6 tons) with Ontario accounting for $70 \%$ of the crop. In Wisconsin, production was $400 \mathrm{t}$ (440.9 tons) in 2000 and has been declining since 1995 when production was 1000 t (1102.3 ton). The ginseng crop is grown from seed whose economic value varies with its availability (Proctor et al., 1999).

Ginseng is grown around the world in a range of climatic zones, mostly between latitudes $34^{\circ}$ and $45^{\circ}$
N (Proctor, 1988). The basic climatic requirements for North American ginseng cultivation have been summarized (Bailey, 1990; Proctor, 1980; Proctor, 1988; Proctor and Bailey, 1987). Included in these summaries are tables for climatic variables such as mean daily temperatures and range, mean date of last frost in the spring and mean annual frost free period.

These requirements relate to the native environment of North American ginseng which is an understory component of deciduous forests of eastern North America. An elevated shade canopy and straw mulch provide appropriate levels of solar radiation for photosynthesis and very little evapotranspiration (Stathers and Bailey, 1986). Air temperatures beneath the crop canopy during the day were up to $6{ }^{\circ} \mathrm{C}\left(10.8^{\circ} \mathrm{F}\right)$ higher than above the canopy. At night air temperatures were up to $2^{\circ} \mathrm{C}\left(3.6^{\circ} \mathrm{F}\right)$ higher beneath the shade canopy.

Spring freeze damage to North American ginseng is rare. Oliver (1998) reported that in British Columbia, Canada, low temperatures about $-\mathbf{5}$ ${ }^{\circ} \mathrm{C}\left(23.0^{\circ} \mathrm{F}\right)$ in mid-May caused extensive damage to plants. Mean date of last frost for this area is about 20 Apr. (Bailey, 1990). The major production area for North American ginseng is the Lake Erie counties of southern Ontario, Canada. In this area spring freeze damage is rare as the mean date of last frost is 12 May (Brown et al., 1968; Proctor, 1988). However, on 21 May 2002, following three to six nights when air temperatures across the ginseng growing area fell below freezing, extensive damage to the crop was evident. Similar damage to the Ontario ginseng crop has not been reported in the last 75 years. The objective of this report is to record this unusual event, and to illustrate and describe the associated damage to the crop.

\section{Study area climate}

The Lake Erie counties of southern Ontario have a variable climate (Brown et al., 1968; Presant and Acton, 1984). This variability can be attributed, in part, to the closeness to Lake Erie. Adjacent to the lake there are thermal effects and on-shore breezes with cooling in the spring and summer. Proximity to water in this region is not the only factor that influences freeze incidence as topography, altitude and natural air drainage all play a role. 
The ginseng producing region is a sand plain with some moraines and dunes (Presant and Acton, 1984). Drainage is considered good and is by short rivers and streams that cut deeply into the plain and flow to Lake Erie. Adjacent to some of the moraines are pockets of wet sands with poor water and air drainage. Because of attractive rental rates, some ginseng growers have planted on these sites without realizing that the incidence of freeze damage is increased in such locations.

Review of weather records shows that the climate of the ginseng growing area is variable (Brown et al., 1968; Presant and Acton, 1984). Although growing season parameters (e.g., freeze-free period) have been developed with associated prediction of variability, the latter is often large (Brown et al., 1968 and discussion below). The mean date for last freeze in the ginseng growing area is about 12 May (Brown et al., 1968). In 4-year-old ginseng gardens at Burford on 17 May 2002 , following a 5 -d period with low temperatures around $5{ }^{\circ} \mathrm{C}\left(41.0{ }^{\circ} \mathrm{F}\right)$

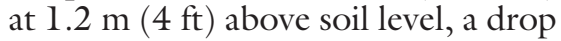
to $0{ }^{\circ} \mathrm{C}\left(32.0^{\circ} \mathrm{F}\right)$ and below (lowest $\left.-3.6^{\circ} \mathrm{C}\left(25.5^{\circ} \mathrm{F}\right)\right)$ occurred for four nights (Fig. 1). Soil temperatures in the same period declined slightly but stayed above $5^{\circ} \mathrm{C}$. There was no freeze damage to the plants in this garden. It

Fig. 1. A record of daily mean high (air high) and low (air low) air temperatures at screen height, $[1.2 \mathrm{~m}(4 \mathrm{ft})]$ and mean soil temperatures (soil) at $15 \mathrm{~cm}(5.9$ inches) from the surface in a 4-year-old ginseng garden from 8 to 24 May 2002; ${ }^{\circ} \mathrm{F}=1.8\left({ }^{\circ} \mathrm{C}\right)+32$.

appears that heat storage in the soil/ mulch system and its upward flow was adequate enough to prevent plant damage. Stathers and Bailey (1986) reported significant absorption of radiation by the leaf canopy.

Some $600 \mathrm{~m}(1968.5 \mathrm{ft})$ to the west at the bottom of a $1.5 \%$ slope extensive damage to seedling and 2 -yearold plants took place. Unfortunately, no weather records are available for these gardens but obviously the cold air had drifted down the gentle slope and pooled in the low-lying area. Damage to 2-year-old plants in this area was more extensive on those plants growing under woven black polyethylene shade than under wooden lath shade. Possibly the cold air that rolled under the black polyethylene was unable to escape, whereas the spaces between the wooden slats allowed escape of the cold air. Stathers and Bailey (1986) reported impedance of radiation emission by black polyethylene shade particularly under low turbulence conditions.

\section{Plant and crop development}

The growth and development of North American ginseng has been described in detail by Proctor and Bailey (1987) and Proctor et al. (2003). To facilitate understanding of the ensuing information a summary of the growth and development is given. The principal method of ginseng propagation is by These cuts also assist in air drainage.

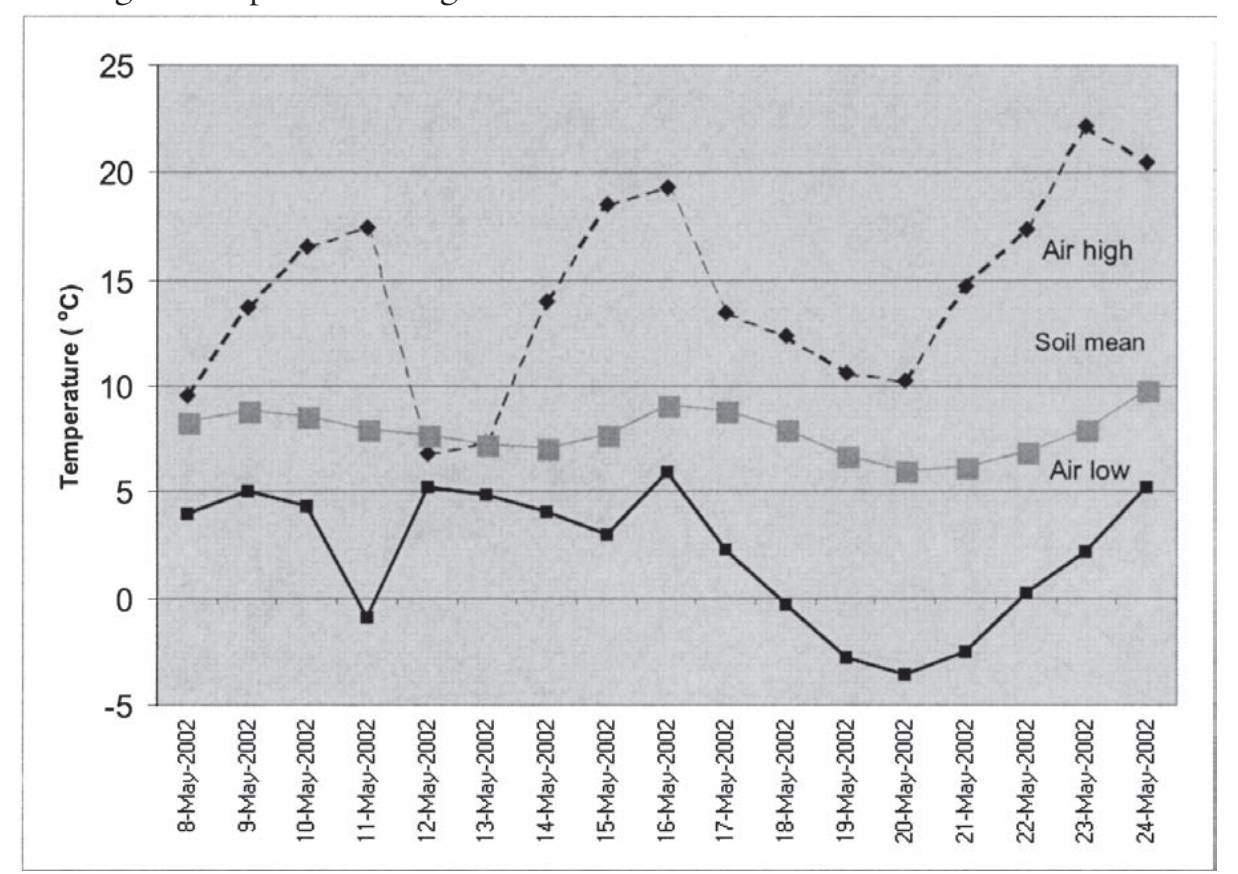

698 seed, which is stratified for about 12 months and then seeded into raised beds in the fall (Proctor and Louttit, 1995). The seedlings emerge in early May and in about 1 month a singlestemmed 5- to $10-\mathrm{cm}(2.0-$ to 3.9 inch) plant terminating in a trifoliate leaf with an area of about $11 \mathrm{~cm}^{2}(1.7$ inch $^{2}$ ) (Hughes and Proctor, 1981) is established. A perennating bud on the seedling is initiated in June. Seedlings do not produce flowers. Growth from the perennating bud in the second growing season shows considerable variation but usually has one stem about 15 to $20 \mathrm{~cm} \mathrm{(5.9} \mathrm{to}$ 7.9 inches) long, a single leaf with three to five leaflets giving a leaf area of about $47 \mathrm{~cm}^{2}\left(7.3\right.$ inch $^{2}$ ) (Hughes and Proctor, 1981) and may produce flowers. Seed production in the second year is usually not sufficient to justify harvesting. In the third year when the perennating budbreaks a single stem arises with the inflorescence on a peduncle (Fiebig et al., 2001) in the axil of the leaves. There will be three leaves each with five leaflets. Seed production in the third and subsequent years will be substantial. In the fourth year the plant will have four leaves. Most plants are harvested for both seed and root at the end of the third year.

Ginseng is a self-thinning crop. For instance, a crop seeded at 300 seeds $/ \mathrm{m}^{2}\left(27.8\right.$ seeds $\left./ \mathrm{ft}^{2}\right)$ will realize only about 260 seedlings $/ \mathrm{m}^{2}(24.2$ seeds $\left./ \mathrm{ft}^{2}\right)$, and about 68 roots $/ \mathrm{m}^{2}$ $\left(6.3\right.$ seeds $\left./ \mathrm{ft}^{2}\right)$ at harvest 4 years later (Proctor et al., 2000). Although this is the accepted ginseng industry expectation a stress such as spring freeze damage could further reduce the plant population.

The ginseng plant avoids low temperature damage to the regenerative perennating bud on the rhizome because the bud is located below the soil surface and protected by soil heat and by insulation from a mulch and frequently, snow. Contractile roots pull the rhizome into the soil (Grushvitzky, 1952). In controlled freezing tests Proctor and Lee (1983) showed that ginseng will regrow after exposure to $-10^{\circ} \mathrm{C}\left(14.0^{\circ} \mathrm{F}\right)$ in common with other field-grown herbaceous perennials (Iles and Agnew, 1993). Although air temperatures across the growing region fell to $-10{ }^{\circ} \mathrm{C}$ the soil temperature was already about $5^{\circ} \mathrm{C}$ (Fig. 1 ) so unbroken perennating buds were not exposed to damaging temperatures. 


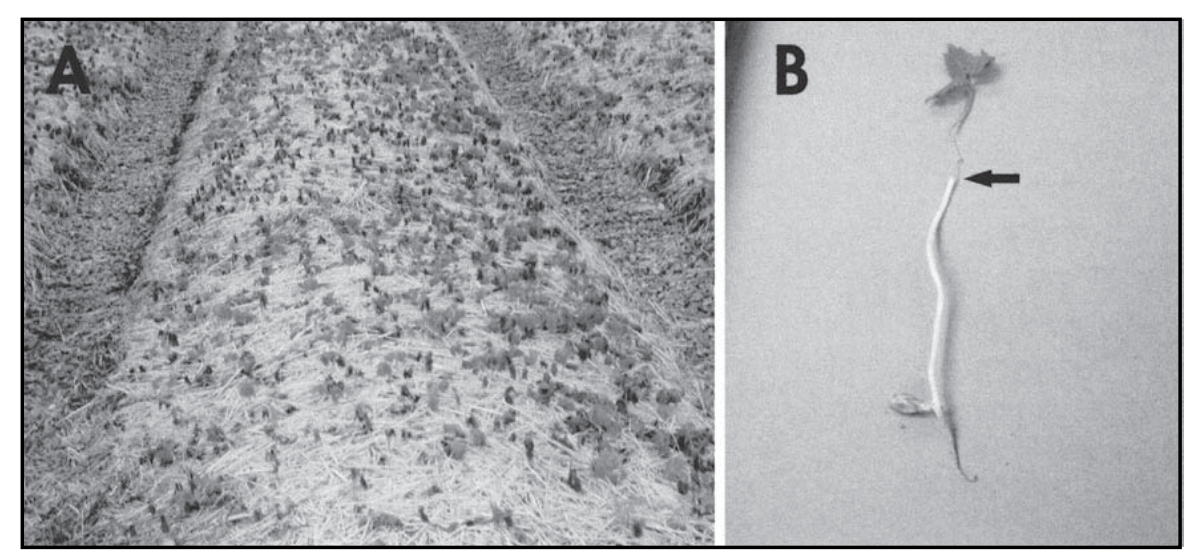

Fig. 2. Photographs of (A) freeze damaged area of a ginseng seedling bed with about 100 plants $/ \mathrm{m}^{2}\left(9.3\right.$ plants $\left./ \mathrm{ft}^{2}\right)$ and $(\mathrm{B})$ whole ginseng seedling with a frozen stem and leaf (above arrow). The stem that was in the mulch and soil (below arrow) was healthy.

\section{Plant damage}

One-year-old Seedings. Some $59 \%$ of growers reported 2 to $50 \%$ damage to individual ginseng gardens (Table 1). Seedling emergence data for one farm in this area showed about $50 \%$ emergence on 23 May 1994 (Proctor et al., 2000). The ginseng seedlings were particularly sensitive to low temperatures. The young emerging succulent leaves were killed, the tops fell over and many plants died back into the straw mulch (Fig. 2). The young seedlings had not had time to accumulate reserves in the roots or initiate a perennating bud. In some cases most plants were lost, and the shade was removed from the crop to destroy any remaining plants and avoid maintenance costs. Reseeding was carried out in Fall 2002. In some areas (e.g., Paris, at the northern edge of the producing area) the seedlings had not emerged through the straw mulch so no damage occurred. Freeze damaged seedling leaves and stems caused susceptibility to the spread of disease. Diagnosis and control of Alternaria diseases was a major concern as freeze damage to stems and Alternaria panax (Howard et al., 1994; Reeleder and Fisher, 1995) infection lesions appeared at similar locations, and the stems toppled at a sharp angle. Freeze damaged stems lacked the distinct tan lesion with a darker border of Alternar$i$ infection. A low level of Alternaria panax overwinters in ginseng gardens on the straw mulch and infected crop residue from the previous year so Alternaria infections on these freeze damaged plants was predicted and diagnosed. Where Alternaria was diagnosed, appropriate control measures were implemented (Ontario Ministry of Agriculture, 2001). These control measures emphasized cultural methods such as removal of side shades to encourage air movement. Application of the registered pesticides chlorothalonil and mancozeb-containing materials [e.g., Dithane (Dow AgroSciences, Indianapolis)] was carried out where necessary. Crop coverage with these control chemicals was emphasized.

TWO-YEAR-OLD PLANTS. About 70\% of growers reported that between 2 and $75 \%$ of their 2 -year-old gardens were damaged (Table 1). Damage ranged from puckered and wilted leaves, to damaged inflorescences, crinkled stems, leaf blackening and even total death of the plant tops (Fig. 3). Since a 2-year-old plant can form a perennating bud, the root may persist and the new budbreak in Spring 2003. However, this regrowth is likely to be highly variable given that the root had to persist in the soil for nearly one year, and damage to the plant occurred just as the perennating bud was forming.

THREE-, FOUR-, AND FIVE-YEAR-OLD PLANTS. Most growers had 3-year-old gardens and reported extensive damage to their plants (Table 1). Damage included low plant populations, bent stems, puckered leaves, leaf tip dieback, swollen and split stems, frozen bent stems below the juncture of the petioles and peduncle, inflorescence damage and botrytis blight infection (Fig. 4) caused by Botrytiscinerea (Bramall and Fisher, 1993; Howard et al., 1994). Botrytis overwinters as sclerotia in plant residue from the previous year. Conidiophores and conidia can be produced early in the spring as the ginseng crop emerges. Spread of the disease can be rapid in older ginseng gardens with dense canopies. As the canopy is established at the beginning of the season any damage to it has effects that last all season long. The initial assessment of this damage was higher

Table 1. Percent of growers reporting freeze damage to ginseng plants in percentage intervals (e.g., 2-10\%) of different ages ( 1 = seedling, $2,3,4$, and 5 years) and associated seed crop loss to 3 - to 5 -year-old plants reported by growers in October 2002. ${ }^{\mathrm{z}}$ Data are based on information from 200 growers cultivating 1740 ha (4299.5 acres).

\begin{tabular}{|c|c|c|c|c|c|c|}
\hline \multirow{3}{*}{$\begin{array}{l}\text { Damage to } \\
\text { plants or } \\
\text { seed crop } \\
\text { reported }(\%)\end{array}$} & \multicolumn{5}{|c|}{ Plant age (years) } & \multirow{3}{*}{$\begin{array}{l}\text { Seed crop } \\
\text { lost in } \\
3 \text { - to } \\
5 \text {-year-old } \\
\text { plants (\%) }\end{array}$} \\
\hline & 1 & 2 & 3 & 4 & 5 & \\
\hline & \multicolumn{5}{|c|}{ Growers reporting (\%) } & \\
\hline None & 30 & 16 & 11 & 16 & 13 & 15 \\
\hline $2-10$ & 28 & 20 & 25 & 9 & 1 & 12 \\
\hline $11-30$ & 18 & 28 & 26 & 11 & 1 & 8 \\
\hline $31-50$ & 13 & 13 & 18 & 9 & 1 & 18 \\
\hline $51-75$ & 2 & 9 & 10 & 9 & 1 & 21 \\
\hline 76-95 & 2 & 6 & 4 & 2 & 0 & 16 \\
\hline$>95$ & 1 & 1 & 0 & 1 & 0 & 4 \\
\hline Growers not having a crop of this age, or seed & 6 & 7 & 6 & 43 & 83 & 6 \\
\hline
\end{tabular}

${ }^{2}$ Adapted from data provided by the Ontario Ginseng Growers Assn., Simcoe. 

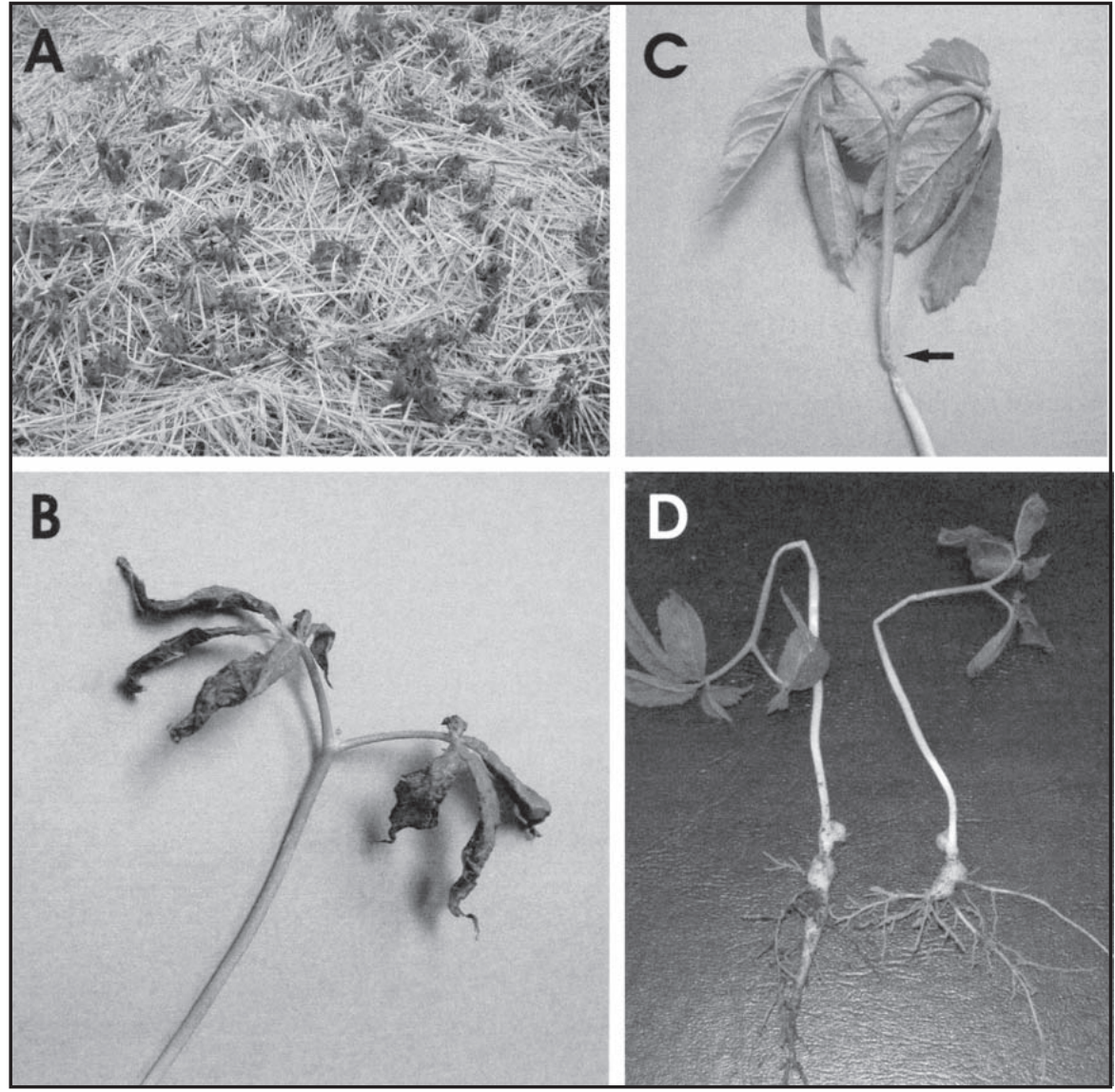

Fig. 3. Photographs from 2-year-old plantings showing: (A) healthy and freeze damaged plants resulting in a sparse plant population, (B) freezed damaged curled leaves, (C) damaged stem (arrow), and (D) whole 2-year-old plants with damaged stems above the soil/mulch interface that caused the tops to topple. than reported later in the growing season (Table 1). For instance, mild damage to stems corked over and the affected plants did not wilt or shrivel. Damage to 4- and 5-year-old gardens was similar to that for three-year-old but only $57 \%$ and $17 \%$ of growers had 3- or 4-year-old gardens respectively. Inflorescence damage was a concern in these mature plants. In some instances inflorescences turned brown, dried up and abscised. In other cases only some of the petioles shriveled leaving some flowers to set fruit and produce seed. Unfortunately, prior to the freeze episode, $23 \%$ of growers had manually removed inflorescences to increase root yield (Proctor et al., 1999). The overall impact of freeze damage and manual removal of the inflorescence was an estimated $25 \%$ reduction in seed yield. This seed shortage resulted in an unknown reduction of seeded area in Fall 2002. Some fortunate growers with excess seed realized enhanced financial returns.

Alternaria and Botrytis both posed problems in mature gardens. Precisely timed Alternaria sprays were needed (Ontario Ministry of Agriculture, 2001) particularly where there was a history of occurrence of this disease and where developing berries were infected. Alternaria infected petioles formed shriveled, tan lesions

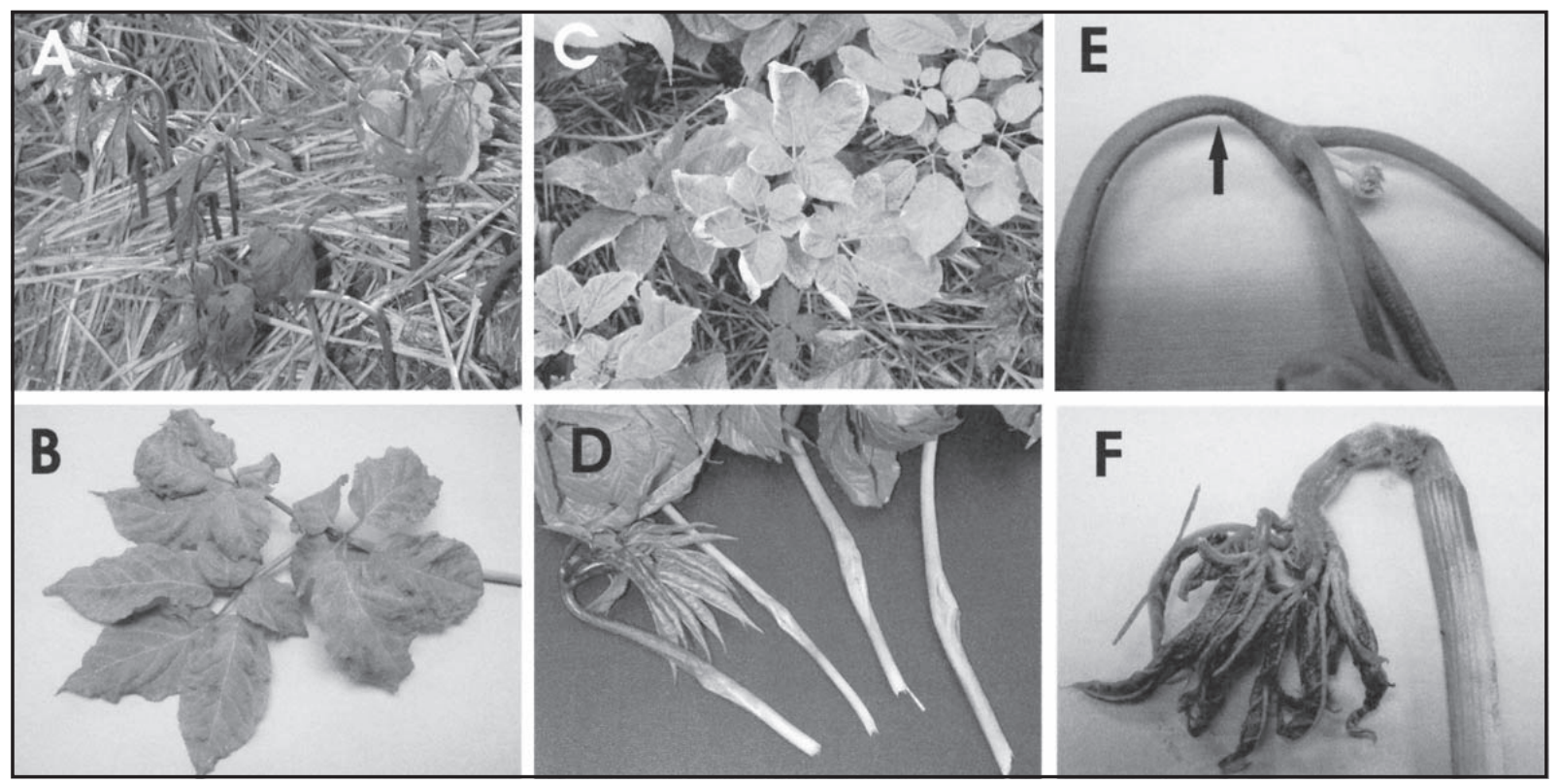

Fig. 4. Photographs from 3-year-old plantings showing: (A) low plant population with some plants with bent stems, (B) puckered leaves, (C) marginal leaf tip die-back, (D) swollen and split stems, (E) upper stem damage (arrow) causing shriveling of the stem and petiole and plant toppling, ideal site for Botrytis infection, and (F) bent stem with advanced symptoms for Botrytis infection. 
followed by seed drop-known as blasting. Alternaria infections developed and spread rapidly and growers removed the side shades to increase air movement and dry the leaves. This further reduced root weights because of dieback of the plant tops in direct sunlight. Conditions for Botrytisinfection were ideal as there was damaged and dead tissue, and several, extended periods of high humidity and temperatures. Botrytisinfected berries and flower heads (Fig. 4F) turned purple and were covered with a fuzzy spore mass. The fungicide fenhexamid [Elevate (Bayer AG, Agrochemicals Division, Monheim am Rhein, Germany)] was granted emergency registration in Canada to combat recurring problems in Botrytis control.

In summary, in addition to seed loss in 2002, root yield loss of $30 \%$ due to the spring freeze damage, coupled with extreme summer heat and late summer heavy rains, high disease incidence, resulted in a total loss of 500 t root dry weight which translates into an estimated \$24.7 million. The results of freeze damage in 2002 will not be fully known for years to come. Growers have used, and will continue to use, management techniques (fertilizers and fungicides, as outlined above) to reduce crop loss. There has been a reevaluation of potential crop growing locations and already the least desirable sites are being avoided.

\section{Literature Cited}

Bailey, W.G. 1990. The adaptation of ginseng to semi-arid environments: The example of British Columbia, Canada. Korean J. Ginseng Sci. 14:297-309.

Brammall, R. and P. Fisher. 1993. Botrytis blight of ginseng. Ontario Ministry of
Agriculture, Food and Rural Affairs, Factsheet $260 / 631$, Government of Ontario, Toronto.

Brown, D.M., G.A. McKay, and L.J. Chapman. 1968. The climate of southern Ontario. Climatological Studies No. 5, Atmospheric Environ. Serv., Environ. Canada, Ottawa.

Fiebig, A.E., J.T.A. Proctor, U. Posluszny, and D.P. Murr. 2001. The North American ginseng inflorescence: Development, floret abscission zone, and the effect of ethylene. Can. J. Bot. 79:1048-1056.

Grushvitzhy, I. 1952. Roots that contract -An important biological characteristic of Panax ginseng. Botanicheskii Zhurnal 37:682-685.

Howard, R.J., J.A. Garland, and W.L. Seaman. 1994. Diseases and pests of vetetable crops in Canada. Can. Phytopathol. Soc., Entomol. Soc. Can., Ottawa.

Hughes, B.R. and J.T.A. Proctor. 1981. Estimation of leaflet, leaf and total leaf area of Panax quinquefolius using linear measurements. J. Amer. Soc. Hort. Sci. 106:167-170.

Iles, J.K. and N.H.Agnew. 1993. Responses of five container-grown herbaceous perennial species to laboratory freezing. HortTechnology 3:192-194.

Oliver, A. 1998. Ginseng production guide for commercial growers. Assn. Ginseng Growers of B.C. and B.C. Min. of Agr., Fisheries and Food, Victoria.

Ontario Ministry of Agriculture. 2001. Production recommendations for ginseng. Ont. Min. Agr., Food Rural Affairs, Toronto, Publ. 610.

Presant, E.W. and C.J. Acton. 1984. The soils of the regional municipality of Haldimand-Norfolk. Ontario Inst. Pedol. Land Resour. Res. Inst. Guelph, Ontario, Rpt. 57.

Proctor, J.T.A. 1980. Some aspects of the
Canadian culture of ginseng (P. quinquefolius L.), particularly the growing environment, p. 39-47. In: Proc. $3^{\text {rd }}$ Intl. Ginseng Symp., Korea Ginseng Res. Inst., Seoul.

Proctor, J.T.A. 1988. The micrometeorological requirements for the culture of ginseng (Panax sp.), p. 129-132. In: Korean Ginseng and Tobacco Res. Inst. Proc. $5^{\text {th }}$ Int. Ginseng Symp., Seoul.

Proctor, J.T.A., and W.G. Bailey. 1987. Ginseng: Industry, botany, and culture. Hort. Rev. 9:188-236.

Proctor, J.T.A. and J.C. Lee. 1983. Some aspects of low-temperature tolerance and mineral nutrition of American ginseng, Panax quinquefolius L., p. 62-69. In: E. Jones and C. Kring (eds.). Proc. $5^{\text {th }}$ Natl. Ginseng Conf., Lexington, Ky.

Proctor, J.T.A. and D. Louttit. 1995. Stratification of American ginseng seed: Embryo growth and temperature. Korean J. Ginseng Sci. 19:171-174.

Proctor, J.T.A., D.C. Percival, and D. Louttit. 1999. Inflorescence removal affects root yield of American ginseng. HortScience 34:82-84.

Proctor, J.T.A., D. Louttit, and J.M. Follett. 2000. Controlled temperature, above-ground stratification of North American ginseng seed. HortTechnology 11:100-103

Proctor, J.T.A., M. Dorais, H. Bleiholder, A. Willis, H. Hack, and V. Meier. 2003. Phenological growth stages of North American ginseng (Panax quinquefolius). Ann. Appl. Biol. (in press).

Reeleder, R.D. and P. Fisher. 1995. Diseases of ginseng. Ont. Min. Agr. Food Rural Affairs Factsheet 260/630. Government of Ontario, Toronto.

Stathers, R.J., and W.G. Bailey. 1986. Energy receipt and partitioning in a ginseng shade canopy and mulch environment. Agr. For. Meteorol. 37:1-14. 